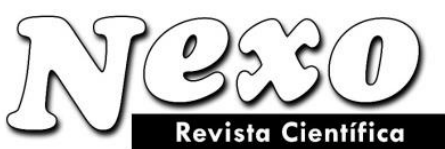

Vol. 36, No. 06, pp. 1761-1767/Diciembre 2021

\title{
Results of laboratory and bench-scale studies of seed dispensers with an electric drive of working tools
}

\section{Resultados de estudios de laboratorio y estudios a escala comparativa de dispensadores de semillas con un accionamiento eléctrico de herramientas de trabajo}

\author{
Anatoly Ivanovich Zavrazhnov ${ }^{1, *}$, Aleksandr Vladimirovich Balashov ${ }^{2}$, Sergey Petrovich \\ Strygin $^{2}$, Nikita Yurievich Pustovarov ${ }^{2}$, Andrey Anatolyevich Zavrazhnov ${ }^{1}$ \\ ${ }^{1}$ Michurinsk State Agrarian University. Michurinsk, Russia. \\ ${ }^{2}$ All-Russian Scientific-Research Institute of Technics and Oil Products Usage in Agriculture RAAS. \\ Tambov, Russia. \\ *email: anatoli.zavrazhnov@ mail.ru
}

(recibido/received: 28-octubre-2021; aceptado/accepted: 07-diciembre-2021)

\begin{abstract}
Mechanical and pneumatic seed drills of both domestic and foreign production are used in Russian farms. They are equipped with a mechanical drive of working tools and an electronic seeding control system. Due to the slipping of the wheels or the breakage of the chains, the sowing of seeds in individual seed dispensers interrupts. According to the results of laboratory and bench-scale studies in respect to soybean seeds, the required power for the electric drive of one seed dispenser was determined, which, depending on the disk rotation speed from 10 to $60 \mathrm{rpm}$, ranged from 30 to $120 \mathrm{~W}$. By calculation, using the analytical expression, the power, required for the fan drive of a 12-row seed drill, was determined, which, depending on the disk rotation speed, ranged from 1.6 to $2.47 \mathrm{~kW}$. A condition is formulated, which will eliminate the probability of shifting and rolling seeds along the furrow after their fall out of the sowing disc rotating in the opposite direction to the movement of the seeder unit, provided correspondence of the linear speed of the sowing disc and the speed of the seeder unit (the effect of zero overlaps). In this case, the trajectory length of the seeds falling to the furrow should be consistent with the speed of the seeder unit and the seeding rate according to the proposed expression.
\end{abstract}

Keywords: seed drills, bench-scale studies, rotation speed.

\section{RESUMEN}

En las granjas rusas se utilizan sembradoras mecánicas y neumáticas de producción nacional y extranjera. Están equipados con un accionamiento mecánico de herramientas de trabajo y un sistema de control de siembra electrónico. Debido al deslizamiento de las ruedas o la rotura de las cadenas, se interrumpe la siembra de semillas en dosificadores de semillas individuales. De acuerdo con los resultados de los estudios de laboratorio y de laboratorio con respecto a las semillas de soja, se determinó la potencia requerida para el accionamiento eléctrico de un dosificador de semillas, la cual, dependiendo de la velocidad de rotación del disco de 10 a $60 \mathrm{rpm}$, osciló entre 30 y $120 \mathrm{~W}$. Por cálculo, utilizando la expresión analítica, se determinó la potencia, necesaria para el accionamiento del ventilador de una 
sembradora de 12 hileras, que, dependiendo de la velocidad de rotación del disco, osciló entre 1,6 y 2,47 $\mathrm{kW}$. Se formula una condición que eliminará la probabilidad de que las semillas se muevan y rueden a lo largo del surco después de su caída del disco de siembra girando en la dirección opuesta al movimiento de la unidad sembradora, siempre que se corresponda con la velocidad lineal del disco de siembra y la velocidad de la unidad sembradora (el efecto de cero solapamientos). En este caso, la longitud de la trayectoria de las semillas que caen al surco debe ser consistente con la velocidad de la unidad sembradora y la tasa de siembra de acuerdo con la expresión propuesta.

Palabras claves: sembradoras, estudios a escala de banco, velocidad de rotación.

\section{INTRODUCTION}

Currently, the size of sown areas in Russia is about 80 mln hectares. In recent years, in the structure of the sown areas, the largest share is occupied by wheat (winter and spring), barley (winter and spring), and sunflower. The share of grain maize, soy, oats, rapeseed, peas, oilseed flax, sugar beet, and buckwheat is also quite high (Kuznetsov et al. 2020; Brizhanskij et al. 2020; Manaenkov et al. 2020).

Mechanical and pneumatic seed drills of both domestic and foreign production with a mechanical drive of working tools and an electronic seeding control system (SCS) are used for sowing row crops in most farms in Russia. The seed dispensers of the seed drills are driven by the support-drive wheels through chain gears, shafts, and gearboxes, while the fan drive of pneumatic seed drills is driven by the tractor PTO shaft through a mechanical transmission system. Due to the slipping of the wheels or the breakage of the chains, the sowing of seeds in individual seed dispensers interrupts. When changing the rotation speed of the fan shaft, the stability of the seed suction to the holes of the sowing disc of the seed dispenser is disturbed. These disadvantages in the operation of seed drills can be eliminated by using an electric drive of seed dispensers and fans, which allows ensuring the autonomy of the drive of each device, independent of the operating conditions of the seeder unit and the stability of the fan regardless of the change in the rotation speed of the tractor PTO shaft. According to (Kverneland Group, 2021), today, when accurately sowing row crops, no more than 20-25\% of Russian farms use GPS-based automatic disconnection of the seed drill sections, which is possible only when using an electric drive of the working tools of the seed drills. This allows controlling the seeding rate of each device and automatically turning it off on the sown areas, as well as to exclude re-sowing on the turn lanes and wedges. Employing an electric drive in seed dispensers of seed drills replaces the mechanical drive elements (shafts, gears, sprockets, chains, and gearboxes) to regulate the seeding rate, which allows reducing the maintenance and mechanical services cost of seeder units (Gorshenin y Abrosimov y Solovyov, 2017; Soloviev, et al. 2021; Solovyov, et al. 2020; Zavrazhnov et al. 2020).

\section{MATERIALS AND METHODS}

Experimental studies of seed dispensers for row crops were carried out in laboratory conditions according to the developed methodology employing a bench with an electrically adjustable disk rotation drive (Figure 1). 


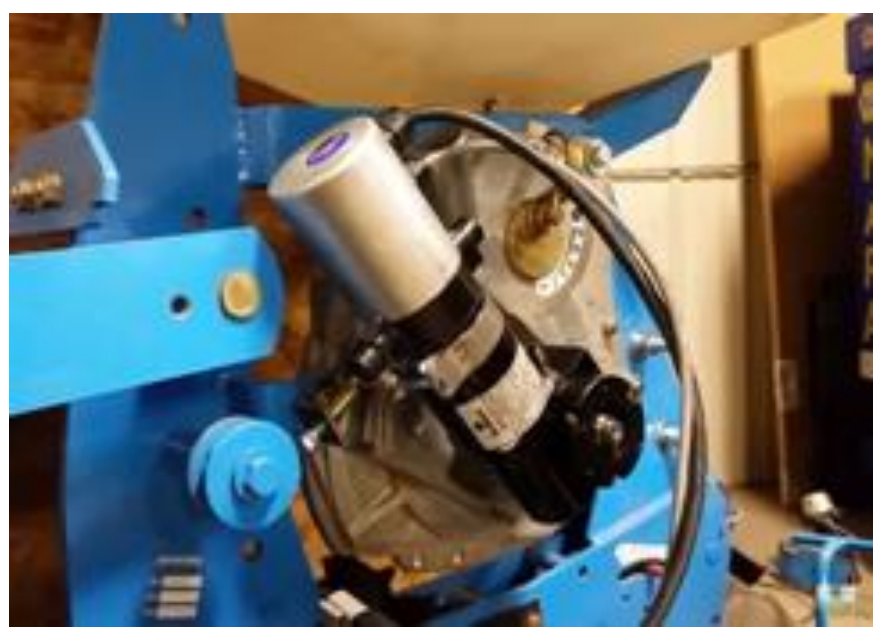

Figure 1. An experimental bench for studying a seed dispenser with an electric disk rotation drive

When carrying out laboratory and bench-scale studies, the time intervals between the ejections of seeds from the seed dispenser were recorded using a seeding sensor installed in a colter, which registered the seeds' flight using an LPT-port attached to a computer and transmits a signal to a computer through a pulse conversion unit.

The required power for the drive of the seed dispenser is determined by the well-known formula (Lovkis et al. 2016):

$$
P=\frac{0.105 \cdot M \cdot n}{\eta}
$$

where $M$ is the torque on the shaft of the sowing disc, $\mathrm{N} \cdot \mathrm{m} ; \mathrm{n}$ is the rotation frequency of the sowing disc, rpm; ${ }^{\eta}$ is the efficiency of the electric drive.

After converting the formulas, presented in (Gorshenin y Abrosimov y Solovyov, 2017), we obtained an expression for determining the required power of the electric fan drive:

$$
P_{\text {в }}=\frac{m \cdot\left(d_{s}-\sqrt{d_{s}^{2}}-\sqrt{d}_{h}^{2}\right) \cdot\left(\omega^{2} \cdot R+g\right) \cdot k_{s a v} \cdot k_{s u c} \cdot V_{v} \cdot Z \cdot N}{\delta \cdot d_{h} \cdot \eta_{\mathrm{v}} \cdot \eta_{\mathrm{dr}}},
$$

where $m$ is the mass of the seed, $\mathrm{kg} ; d_{\mathrm{s}}$ is the diameter of the seed, $\mathrm{m} ; d_{\text {or }}$ is the diameter of the hole, $\mathrm{m} ; R$ is the radius of the circle of the hole centers, $\mathrm{m} ; \omega$ is the rotation frequency of the sowing disc, $\mathrm{s}^{-1} ; g$ is the acceleration of gravity, $\mathrm{m} / \mathrm{s}^{2} ; k_{s a f}$ is the safety factor, $k_{s a f}=1.2 ; k_{s u c}$ is the suction coefficient, equal to the ratio of the air speed in the hole with the seed to the air speed in the hole without the seed, $k_{s u c}=0.55$ $0.72 ; V$ is the air flow velocity in the suction hole of the plate, $\mathrm{m} / \mathrm{s} ; Z$ is the number of holes on the sowing disc, pcs; $N$ is the number of seed dispensers on the seed drill, pcs.; $\delta$ is the proportionality coefficient, which takes into account the total effect of various forces; $\eta_{\mathrm{v}}$ is the efficiency of the electric fan drive.

To exclude the possibility of shifting and rolling seeds along the furrow after they fall out of the sowing disc, rotating in the direction opposite to the movement of the seeder unit, the linear speed of the seeder 
unit plate must correspond to the speed of the seeder unit (zero overlap effect), i.e. the following condition must be met:

$$
n_{p} \cdot R_{p}=n_{w} \cdot R_{w}
$$

where $n_{p}, n_{w}$ are the rotation frequencies of the sowing disc and the support-drive wheel of the seed drill, respectively; $R_{p}, R_{w}$ are the radii of the sowing disc and the support-drive wheel of the seed drill, respectively.

At that, the length of the seed fall trajectory to the furrow must be consistent with the speed of the seeder unit and seeding rate according to the proposed equation, obtained by taking into account the falling speed of seeds according to the known laws of change in horizontal and vertical flight range of a body (distance traveled by the body along the horizontal axis for a certain time), thrown horizontally, and expressions to determine the rotation frequency of the sowing disc, agreed with the seeding rate and speed of seeder unit, presented in (Kuznetsov et al. 2014)

$$
L=\frac{V_{a} \cdot k}{l_{s} \cdot q} \cdot \sqrt{\frac{2 \cdot h}{g}},
$$

where $V_{a}$ is the speed of the seeder unit, $\mathrm{m} / \mathrm{s} ; k_{\text {is }}$ the ratio of the diameters of the sowing disc and the support-drive wheel of the seed drill; ${ }^{l}{ }$ is the distance between the seeds along the length of the row, $\mathrm{m}$; $q$ is the seeding rate, pcs $/ \mathrm{m} ; h_{\text {is }}$ the height of the sensor position relative to the side surface of the plate, $\mathrm{m} ; g$ is the acceleration of gravity, $\mathrm{m} / \mathrm{s}^{2}$.

\section{RESULTS AND DISCUSSION}

Experimental studies have revealed that the driver of the sowing disc of the seed dispenser of the MS-8 seed drill with a diameter of $168 \mathrm{~mm}$ powered by a DC electric motor FL57 BL S04 when changing its rotation speed from 10 to $60 \mathrm{rpm}$, which corresponds to the linear speed of the sowing disc from 0.18 to $1.06 \mathrm{~m} / \mathrm{s}$, when sowing seeds of various row crops, will require from 30 to $130 \mathrm{~W}$ (Gorshenin $\mathrm{y}$ Abrosimov y Solovyov, 2017) (Figure 2).
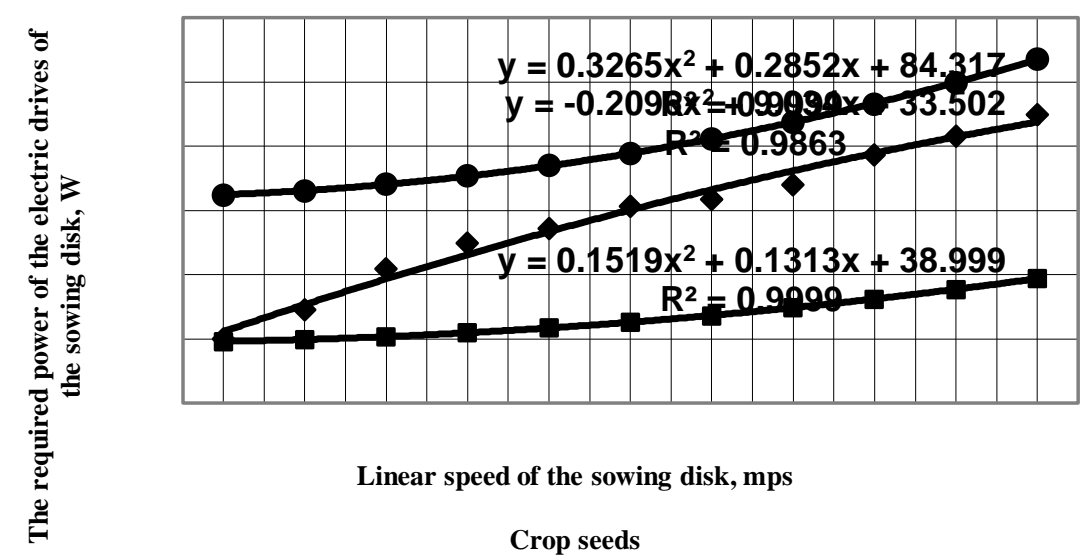

Linear speed of the sowing disk, mps

$$
\begin{aligned}
& \text { Crop seeds } \\
& \text { ४ soybean ๑ sugar beet } \square \text { sunflower }
\end{aligned}
$$

Figure 2. Power of the electric driver per drive of one seed dispenser 
A numerical experiment, based on the expression (2), allowed determining the power required for the fan drive of a 12-row seed drill when sowing soybean seeds, depending on the specified disk rotation speed, which varied from 1.6 to $2.47 \mathrm{~kW}$. At that, the total required power of DC electric engine installed on this seed drill to drive all seed dispensers and a fan, when sowing soybeans at an agronomically justified rotation speed of the sowing disks, which ensures reliable suction of seeds to the disc holes within 20-30 rpm, is no more than $3.75 \mathrm{~kW}$ (Figure 3).

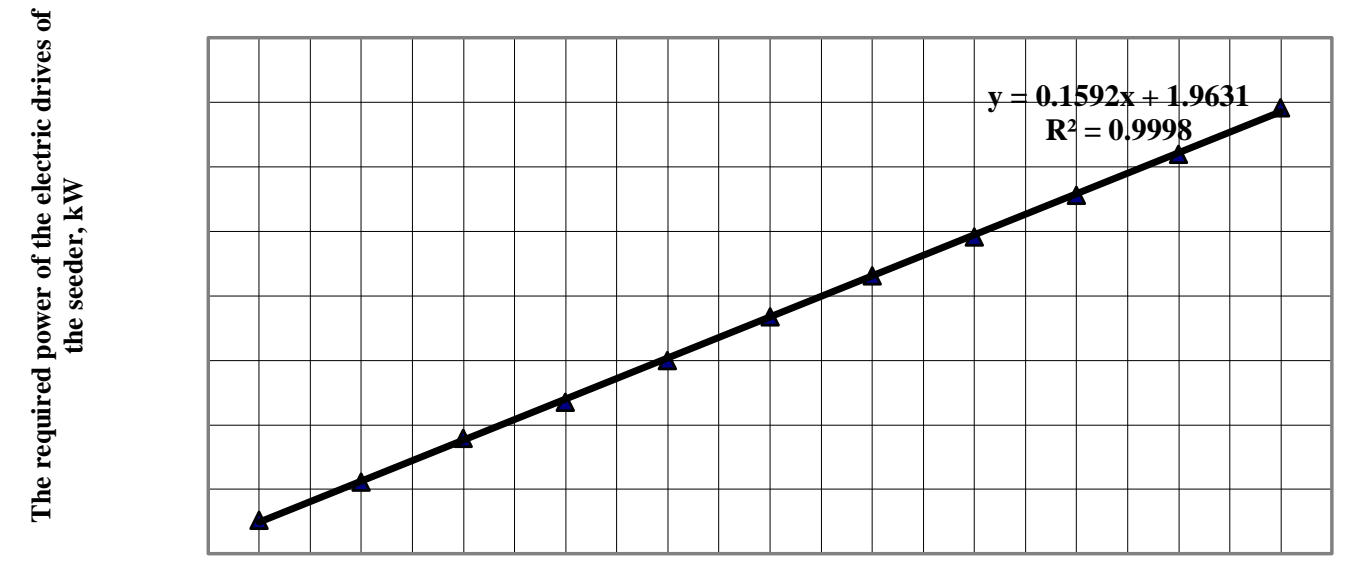

Linear speed of the sowing disk, mps

Figure 3. The total power of the electric drives of all seed dispensers and the fan

The control of the seeder unit operation with an electrically-driven seed drill should be integrated with the monitor of the SCS installed in the tractor cab, and carried out according to the developed algorithm shown in Figure 4.

At the beginning of the work, the SCS requires entering the required seeding rate, as well as entering the number of cells (holes) on the seeding disk to determine the conformity factor (between the rotation speed of the seed dispenser disk and the required seeding rate). Further, after the seeder unit starts moving, the seeding sensors of each seed dispenser are interrogated, and if the current seeding rate corresponds to the set one, then the seed dispensers continue operating in the current mode. If the current seeding rate deviates from the set one, SSCS transmits a control signal to the electric driver that lowers or increases the conformity factor to reach the compliance of the current seeding rate with the required one. The change in the conformity factor is carried out within the range from 0.875 to 1.125 to ensure compliance with the linear velocities of the seeds and the seeder unit. If the deviation of the conformity factor is exceeded, a signal is transmitted to the machine operator about the excess of deviations, which requires stopping the seeder unit to eliminate the causes of problems. 


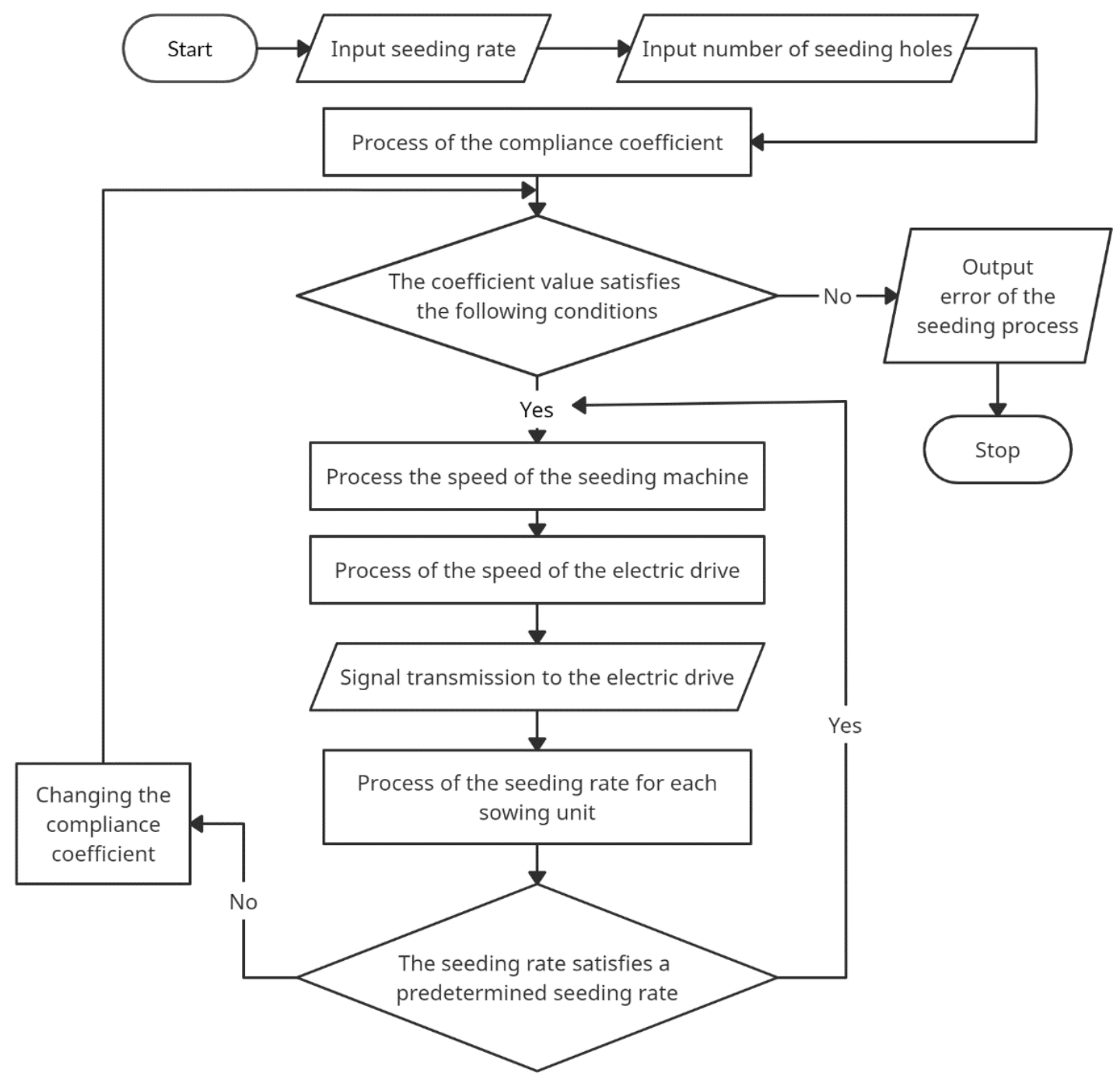

Figure 4. The algorithm for controlling the operation of a seeder unit with a seed drill, equipped with an electric drive of working tools

\section{CONCLUSION}

The electric drive of the seed dispensers and the fan of the row-crop seed drill allows maintaining the stability of the seeding rate in each row and a constant high speed of the seeder unit, which does not depend on the rotation frequency of the seeding disk. Using SCS ensures high accuracy of seeding by each section and their uniform distribution along the row, as well as timely informing the operator about the technical failures of the seed drill, for example, stopping seeding by one or several units, and clogging the colters with soil.

\section{ACKNOWLEDGMENTS}

The research results presented in the article were obtained as part of the implementation of the Agreement No. 075-11-2019-041 of November 22, 2019, between the Ministry of Science and Higher Education of the Russian Federation and JSC Millerovoselmash for conducting R\&D on the topic "Creating high-tech production of multifunctional complexes for sowing and cultivating row crops and vegetable crops in the 
system of accurate and zero arable farming based on intelligent mechatronic modules". The research is performed in the organization of the General Contractor (Federal State Budgetary Educational Institution of Further Professional Education Michurinsk State Agrarian University).

\section{REFERENCES}

Brizhanskij, L.V., Brizhanskaya, Yu.A., Lasica, A.M., Dorohova, A.M. (2020). Effect of low-intensity laser radiation on sugar content in sugar beet root crops obtained from seeds treated with a quantum generator. Journal of Physics: Conference Series, 1679(2), 022026.

Gorshenin, V.I., Abrosimov, A.G., Solovyov, S.V. (2017). Substantiation of the design-mode parameters of the sowing disc of a mechanical beet seed drill. Bulletin of the Michurinsk State Agrarian University, 1. 132-140.

Kuznetsov, P., Solovyev, S., Gorshenin, V., Manaenkov, K. (2020). Reduction of soil layer losses when harvesting sugar beet in the conditions of the central black earth region. E3S Web of Conferences, 210,04007 .

Kuznetsov, P.N., Gorshenin, V.I., Solovyov, S.V., Abrosimov, A.G. (2014). Improved technology of cultivation and harvesting of sugar beet in the conditions of the Tambov Region. Bulletin of the Michurinsk State Agrarian University, 6, 53-56.

Kverneland Group. (2021). The implementation of precision farming technologies in Russian crop production will reach $90 \%$ by 2035 . https://www.agroinvestor.ru/business-pages/35181-k-2035-goduvnedrenie

Lovkis, V.B., A.V. Zakharov, N. N. Stasyukevich, A. N. Stasyukevich. (2016). Justification and calculation of the electric drive scheme of the pneumatic seed drill of the combined tillage-sowing unit. Mechanization and Electrification of Agriculture. Interdepartmental thematic collection. Issue 50. Minsk, 2016, pp. 193-199.

Manaenkov, K.A., Khatuntsev, V.V., Gordeev, A.S., Korotkov, A.A., Gorshenin, V.I. (2020). Analysis of the uniformity of the distribution of herbicides in the intercostal zone with a bar with a deviating section. IOP Conference Series: Materials Science and Engineering, 919(3), 032008.

Soloviev, S.V., Abrosimov, A.G., Dyachkov, S.V., Bakharev, A.A., Kartechina, N.V., Zavrazhnov, A.A. (2021). Theoretical substantiation of the design of the opener of the beet seeder. IOP Conference Series: Earth and Environmental Science, 677(4), 042114.

Solovyov, S.V., Abrosimov, A.G., Gorshenin, V.I., Drobyshev, I.A. (2020). Resource-saving when harvesting sugar beet in conditions of high soil humidity. Proceedings of the All-Russian scientific and practical conference "Innovative approaches to the development of technologies for the production, storage, and processing of crop cluster products". Michurinsk, 202-205.

Zavrazhnov, A.I., Zuglenok, N.V., Zavrazhnov, A.A., Tolstoshein, S.S., Koltsov, S.M. (2020). Mathematical modeling of the temperature regime in a ventilated pile of sugar beet. IOP Conference Series: Materials Science and Engineering, 919(6), 062067. 